\title{
Intercultural missional leadership: Theological foundation and biblical narratives
}

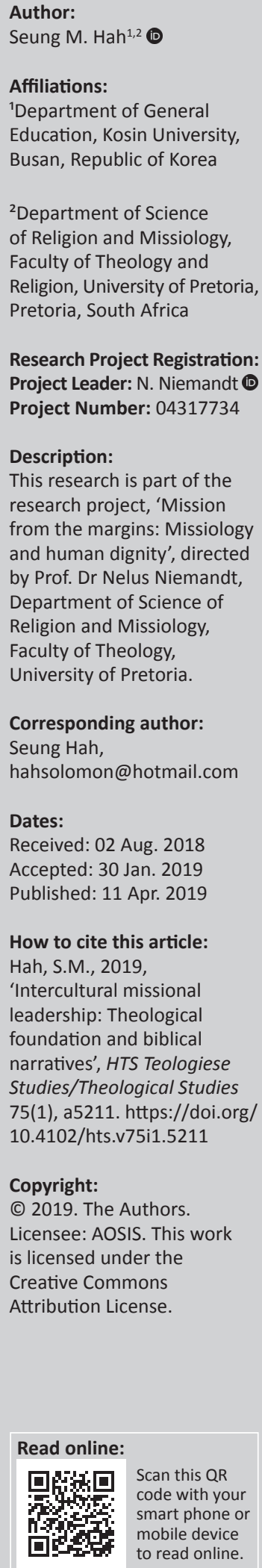

Research Project Registration: Project Leader: N. Niemandt (1) Project Number: 04317734

\section{Description:}

This research is part of the research project, 'Mission from the margins: Missiology and human dignity', directed by Prof. Dr Nelus Niemandt, Department of Science of Religion and Missiology, Faculty of Theology, University of Pretoria.

Corresponding author: Seung Hah, hahsolomon@hotmail.com

Dates:

Received: 02 Aug. 2018 Accepted: 30 Jan. 2019 Published: 11 Apr. 2019

How to cite this article: Hah, S.M., 2019, 'Intercultural missional leadership: Theological foundation and biblical narratives', HTS Teologiese Studies/Theological Studies 75(1), a5211. https://doi.org/ 10.4102/hts.v75i1.5211

\section{Copyright:}

(c) 2019. The Authors. Licensee: AOSIS. This work is licensed under the Creative Commons Attribution License.

This article explores the concept and practice of the missional leadership from three perspectives: the biblical worldview, cultural mandate and narratives of biblical examples. The research explores two elements of missional leadership, which is comparable to the leadership theory as it delves into the concept of 'missional'. This research also unearths understanding the relationship between missional leadership in intercultural environments to the biblical worldview that is based on biblical theology. Furthermore, the exploration seeks to find a relationship between the intercultural missional leadership and the cultural mandate endowed by the triune God to mankind as God's image. In addition, the research also carefully looks into the following biblical models that exemplify intercultural missional leadership: Moses, Jesus Christ and the apostle Paul. Narratives of the Bible show that God reveals his leadership through his providence to accomplish his goal according to his pleasing will, as God is the only resource to intercultural missional leadership. This study seeks to demonstrate how missional leadership in missiology coincides with theological common concepts of the biblical worldview and the cultural mandate in the biblical theology, which will be exemplified through biblical narratives. Both have the same goal to accomplish God's kingdom according to the timeline of the historical phases in biblical worldview: creation, fall, redemption and restoration. It investigates present-time applicable principles through three biblical narratives, providing a reasonable basis of correlation between culture and the gospel.

Keywords: Intercultural; Missional; Leadership; Biblical Worldview; Cultural Mandate.

\section{Introduction}

This article summarises a portion of my dissertation: Intercultural missional leadership: A narrative approach focusing on Tabeh village missional work in Cambodia. This study is an exploration of missional leadership in intercultural environments coinciding with the idea of redemptive history in biblical theology under the broader study of theological foundation.

The research examines biblical narratives of intercultural missional leadership through the lens of Moses, Apostle Paul and Jesus.

The reasoning behind the chosen narratives is due to the following: Jesus is always the only one who accomplishes the consummation of missional leadership in an intercultural environment, and the one who accomplishes redemptive history. Moses is among the three illustrations because he exemplifies leadership in times of liminality and crisis, as told in the first five books of the Old Testament. The Apostle Paul wrote a number of New Testament epistles, and practiced his own form of missional leadership in Asia Minor regions, Macedonia, Greece and Rome in the context of its intercultural environments. The research will use a biographical narrative approach to investigate aspects of leadership in the style and praxis of Jesus, Moses and Paul. To enrich the current understanding of missional leadership, it is important to use insights from this investigation.

\section{Nature of missional leadership and its two elements: Baptism and discipleship}

Missional leadership is a key topic in the 21st century missiology. There are two essential elements of missional leadership: baptism and discipleship. The two elements are much of the same two attributes of contemporary leadership theories: human relations and mission accomplishment (Hah 2013:44). For missional leadership, it focuses on relation to God first, not only human relations of the contemporary leadership theory. 
Discipleship of missional leadership functions to carry the same role of missional accomplishment within the theory of contemporary leadership as God's image bearer. It includes all stages of nurturing process including baptism, an important element of missional leadership that relentlessly pursues a missional goal to bear God's image and evangelise to the world. The missional goal of discipleship is comprised of baptism and proceeds to restore and accomplish the image of God. Baptism represents a milestone in life and strengthens the relationship between the triune God and us as bearers of God's image.

Callahan (2009:120-146) discusses the role of baptism in the formation of lay missional leaders. She (2009:126) says baptism is something flowing out of God's own Trinitarian nature and is a symbol of entering the relationship with the triune God. She argues from 2 Corinthians 12 that all the various gifts originated from baptism and that their roots lie in the Holy Spirit. For Callahan (2009:131) baptism is both the starting line of missional leadership and the factor leading them to commit themselves to God. She (2009:137) emphasises that a missional approach is the solution for the integration between theory and practice of Christian life.

Elton (2009) also emphasises the importance of baptism in missional leadership. He (2009:199) believes Christians partake in both the death and the resurrection of Christ through baptism. Baptism is a pledge to be a new creature with Christ; dying to earthly things and arising to heavenly things. It is a one-time calling for a lifetime journey.

For nature of missional leadership, it needs to investigate the concept of 'missional'. Citing Karl Barth and David Bosch, Guder (1998:4-5) consolidates that the concept missional, which is focused on 'God as a missionary', is developed in a similar context as the theology of God's mission. He means that the church does not do mission; it is mission itself. The church is God's sent people. He (1998:8) also says that the re-orientation of theology must serve the renewal of churches.

The conception of God's mission, 'Missio Dei', was found from Karl Hartenstein's first use in 1934 and his theological view on his publication after Willingen in 1952 (Schwarz 1984:126). His early view took Karl Barth's theological viewpoint, emphasising mutual relationships among the triune God. Hartenstein adapts his theological point in missiology from Bart's theological view, 'Revelation theology for missions' (Schuster 2002:56; Schwarz 1984:126).

Meanwhile, Ott, Strauss and Tennent (2010:82) provide their theological basis on the mission of God. It introduces the threefold purpose of mission, suggested by a 17th-century Calvinist theologian, Gisbertus Voetius (1589-1676): 'The glory of God is the ultimate end of mission; conversion and church planting are penultimate'. They confirm that even the kingdom of God is subordinate to God's glory, citing Voetius' saying: 'God is not only the first cause but also the ultimate goal of missions' (Jongeneel 1991:68).
Bavinck (1960:158) builds on Voetius' understanding, devoting a whole chapter to 'The Threefold Aim' concluding, 'The aim of mission is thus preoccupied with God, with his glory, with his kingdom'. Following the Calvinists Voetius and Bavinck, Ott, Strauss and Tennent (2010:82-83) argue that the end of mission lies in the Doxology of God himself. And as to the purpose and nature of mission, it concludes as follows (2010:105): mission is a sign of the kingdom and an invitation to the nations to enter the kingdom and share the hope of the kingdom promised in Christ's return. The purpose and nature of mission is not only in personal salvation but also in the restoration of God's reign over his people.

Thus, mission is a sign of the Kingdom of God and an invitation to the nations to enter the Kingdom and share the hope of the Kingdom promised in Christ's return.

Buys (2013:95-96) interprets 'missional' as the 'restorations to be done in all spheres for the Kingdom of God' and shows that biblical and Reformed faith supports a holistic integral mission such as caring for the poor, widows and orphans. With respect to expansion of God's kingdom, the Reformed tradition relates to and supports the missional.

Buys (2013) emphasises that real Calvinism works for a world, not separated, but conquered. Missional ministry is concerned with the coming of the Kingdom of God. Buys states missional ministry as follows:

Our understanding of the universal effects of sin should lead us to seek community transformation as the reversal of sin and its consequences; and to seek the restoration of God's order in creation, including God's intent for humans to be his imagebearers in all aspects of their lives. (p. 95)

Goheen (2014:78) suggests rethinking of the role of the church not only for individual faith but also for restoration or renewal of all creation as follows: the final goal of the church cannot be the upbuilding of the individual believer by the church as institution or even the ecclesial community; rather, it must be the renewal of all humankind, of all of humankind's life and of all creation. He (2014:87) cites David Bosch: 'From a theology of mission to a missional theology'. It denotes that the meaning of the term is changing from 'theology of mission' to 'missional theology'. This is an expression that contains not only the biblical mission itself but also the whole theological sphere regarding the calling of the church to mission.

It implies that the church is nothing but a means of mission - never an agent that directly drives its mission. Goheen's explanation accords with the worldview understood by the Reformed perspective. He clearly states that Christ did come to establish the church to restore the world. The reason Christ comes and builds his church is not to establish a Christendom by expanding his church but to restore the whole fallen spheres of the world through the church, that is, through the chosen people. 
From the above discussions, it reaches some clear results. Firstly, missional leadership has two essential elements: one for baptism as a missional relationship between the triune God and his people, the other for discipleship as a bearer of God's image. Secondly, discipleship is a nurturing process in missional leadership comprised of baptism. Thirdly, baptism is a critical chance to strengthen a mutual relationship between the triune God and us in missional leadership. Fourthly, the concept of 'missional' origins from the concept of 'Missio Dei'. Fifthly, missional leadership seeks to glorify God not only through building God's kingdom but also as bearing God's image.

\section{Theological relevance between the missional and the biblical worldview}

It is interesting to study the missional concept from the perspectives of both biblical theology and the biblical worldview. Interpreting the Bible, De Graaf ([1977] 2011:17) emphasised the illumination from the redemptive-historical perspective, by illustrating its contents from creation to the conquest of Canaan. He tells the whole Bible should be regarded as the self-revelation of God.

A similar argument is used by some biblical scholars: Van Gemeren (1988), who explains the Bible as a salvation story that started from the creation up to the New Jerusalem. Kaiser (2008) emphasises the necessity of the biblicaltheological perspective in understanding the Bible. His point (2008:25) is the Bible should not be read fragmentally, but comprehensively since the whole Bible itself is a big story from a covenant perspective.

Geerhardus Vos (1948:38-40) explains the redemptive event, which appears in progress: like a tree is to grow from a seed to its full length. Biblical theology explains also that all historical relations connected to the biblical events have organic relationships among themselves. For Vos (1948:5), biblical theology is 'a branch of exegetical theology which deals with the process of the self-revelation of God deposited in the bible'. Revelation appears in the big picture with its direction and integrity, like the unfolding of God's own master plan.

Hamilton (2014:15) introduces biblical theology as the interpretative perspective of the biblical authors, which comprises the socio-cultural backgrounds of the authors' assumptions and presuppositions, associations and identifications, truths and symbols. Goldsworthy (2012:27) introduces a Christ-centred biblical theology as the study of the matrix of divine revelation in the Bible as a whole, underscoring the importance of biblical revelation and its unified progression. For him, Christ is both the centre of biblical theology. He regards Christ as the link between the Testaments as the centre of God's plan begun at creation and to be completed in the new creation.

Scholars emphasise that the biblical perspective indicates the Bible is not merely a catechism for the salvation of man. It should be noticed that the Bible also mentions historical facts from narrations of the creation to the Revelation of John. The history shows a stepwise and gradual progression towards a specific goal.

Wright (2006:265), therefore, says that the big picture of the redemptive history reveals changes of worldview throughout the whole Bible. The Bible has four (or five) historical phases in the progression of revelation: creation, fall, redemption and restoration (or one may add 'consummation'). Those are equivalent to the four steps of historical changes in the Christian worldview (Helm 1994:94). Helm (1994:102-104) deals with creation, fall, redemption, and restoration and explains that God has revealed his providence through covenants for the relationship between him and his people.

Wolters and Goheen (2005) present a three-step phase as the Christian worldview frame: creation, fall and redemption. Goheen (Wolters \& Goheen 2005:142) sees the relation between worldview and mission in a Postscript: worldview elaboration plays a channelling role, bringing the gospel to meet the life needs of the church in its mission in the world.

It means that the big flow of the Bible story appears through our worldview and towards the world. He (2005:127-132) argues that the big theme of the providence of God known by the biblical-theological perspective, emphasises the role of the missional church through the recognition of the Christian worldview composed of the historical phases of creation, fall and redemption.

Anderson (1994) explains Christ as the new creation of God in his book, written with the biblical-theological perspective. Christ was God's new creation and we were created in Christ as a new community. Christ takes the role of linking the redemptive history in the midst of biblical theology.

What can be read from the big picture of the biblical story, based on the biblical theology, is that the whole process of redemption from creation to the new creation goes through the historical phases of the master plan of God's providence. It also appears towards the world through the lives of the Christians, who recognise the biblical worldview in the frame of which is creation, fall, redemption and restoration.

Though all have an outward face, citing C.J.H. Wright, Logan (2013:6) affirms 'missional' is neither a synonym of 'mission' nor a synonym of 'evangelism'. It implies Christians, as both the Church's and God's witnesses, should not only go and reach out with mercy to the world but also to try to transform our community. The concept of missional exists to serve the world with the biblical worldview. Undoubtedly, the biblical worldview and the concept of missional are inextricably related.

\section{Missional leadership for the cultural mandate}

The cultural mandate refers to the command of the triune God's missional leadership he entrusted to mankind. 
The triune God created all the creatures and rules over them all with his missional leadership. The cultural mandate means the God-given mission for us humans to rule over the world and all the creatures living in the world according to his will (Gn 1:28).

The mandate was given to the first couple, Adam and Eve, and after them to the whole of humankind (Gn 1:27; Hah 2015:73). The first family, Adam and Eve, however, had not only failed in carrying out the mandate, but also tried to usurp God's sovereignty: 'For God knows that when you eat of it your eyes will be opened, and you will be like God, knowing good and evil' (Gn 3:5). The only way to regain the mandate that was lost since the fall of Adam is to believe in Jesus as Christ: the image of God who restored the relationship between God and man. He has the possibility to perform the authority of the cultural mandate. Genesis 1:26-28 mentions the cultural mandate.

The phrases 'in our image (tselem)' and 'in our likeness (demuth)' had been variously interpreted (Hah 2015:143). The early Church-fathers, Origen (185 254) and Irenaeus (125 202) understood them as God's attributes or traits and those had been supported by most church scholars in history. In the 16th century, however, Luther and Calvin changed the interpretation. Specially, Calvin states there is no distinction in meaning between the image (tselem) and the likeness (demuth) (Calvin's Christian Institutes, 1.15.4; Calvin 2008:107). They were not understood as characters or traits, but as relations with regard to God. Calvin also interpreted them partly ontologically. He argued that the image had been destroyed but not completely; at least, there remained the knowledge, the righteousness and the holiness to be renewed based on Ephesians 4:24 and Colossians 3:10 (Calvin 2008:107).

Since the 19th-century, Reformed theologians tend to interpret the image of God more relational. Hoekema ([1986] 1994:13) said the double words 'image and likeness' indicate the same thing. Berkouwer (1984:69) also said the two words are not different but reflect something of the relationship between God and humans. Such an idea had been found in Kuyper and in Herman Bavinck (Berkouwer 1984:68). Reasonably speaking, image and likeness are repetitive words. When Calvin interpreted them, though partially ontologically, he did not take them directly from Genesis 1:28 but from Ephesians 4:24 and Colossians 3:10. According to the attributes of the triune God ruling over all creatures, the created humans have an intrinsic attribute of ruling over the living creatures (Baker 1991:37-39; Wright 2006:422).

Hoekema ([1986] 1994:79) pays attention to the two words 'subdue' and 'have dominion over' in Genesis 1:28, on the relationship between man and nature. He explains that verb 'subdue' is a form of the Hebrew kabasch, which means 'to subdue' or 'bring into bondage'. He ([1986] 1994:79) explains it in detail; 'it means that man is to explore the resources of the earth, to cultivate its land, to mine its buried treasures'.
Hoekema also explains that the Hebrew word, raddah, means 'have dominion over', 'to rule' or 'to dominate'. His ([1986] 1994:79) detailed explanation is as follows: 'it is specially said that humankind shall have dominion over the animals'. His point is that man is allowed in Genesis 1:28 to develop and take care of the resources.

Hoekema ([1986] 1994:81) deploys his argument to the next step for the three relationships: relationships among God, man and nature. He ([1986] 1994:93) insists that this idea comes from the 'perfection of the image'. He notes that Genesis 1:28 indicates that in future, human's image will be like God's perfect image (1 Cor 15:44). He ([1986] 1994:93) points out, 'this perfection will concern, first and most importantly, our relation to God'. The assertion of Hoekema points to the three relationships among the five imperative commands in Genesis 1:28: be fruitful, increase in number, fill the earth, subdue it and rule over all the living creatures. The first four commands come down to the last command; 'rule over', in sentence tectonics.

The structure of the sentence is as follows: it shows that man has to subdue the earth to rule over all the living creatures; to fill the earth to subdue it, and to be fruitful and increase in number to fill the earth. And the last command of the cultural mandate, that is, ruling over all the living creatures, means ruling over them according to God's will. To glorify God, it demands man, as the image of God, to rule with justice and peace. As God governs all creatures with leadership, so should we exemplify accordingly.

It also shows that the leadership of the triune God is being carried towards the world, through man, God's image bearer. It means that the role of man is the most important axis in maintaining the creation order (Hah 2015:147). It is closely related to the missional leadership of the triune God, who restores the creation order through the incarnation. Missional leadership is revealed and gets completed via the incarnation of God. Missional leadership shows the consistent procession towards one direction to the goal of consummation of the universe of the first creation ( $\operatorname{Rv} 21: 1 ; 2 \mathrm{Pt} 3: 12-13)$. And it makes the assumption that the purpose of the missional goal is to glorify God.

To receive Jesus as Christ means that the restored images of God through Jesus Christ are empowered with the cultural mandate, that is, the properly performing authority of the mandate. It reveals the missional leadership of the triune God towards this world, revealed by the work of incarnation through the death and resurrection of Jesus. The incarnation is the proper basis of performing missional leadership. Therefore, only by receiving Jesus Christ can man in the fallen world be restored to the humanity of the new creation. In other words, the only basis to be re-empowered with the performing authority of the cultural mandate is to receive Jesus as Christ, and that is to perfectly participate in God's missional leadership. 


\section{Biblical narrative examples for missional leadership in intercultural society}

Kirk (2000) also writes that the gospel is situated in the middle of culture. He (2000:75) describes the importance of the understanding of culture in proclaiming the gospel. It implies that culture affects every aspect of mission and also can never be ignored in interpreting the context of the biblical narratives. In spite of Kirk's assertion, some doubt the biblical context not being applicable to the 21st-century context. They deem examining biblical contexts is improper to compare and apply to the 21st century postmodern time. Surely, the biblical context differs from the context of current time.

In spite of some doubts, it still should try to find principles or features of leadership in an exploration of biblical narratives that might be applicable to the current context. A commonality is in how the gospel lies at intercultural environment in current and biblical times in following three narratives. The argument is that culture motivates or elevates in functioning for the recovery of the corrupted order of creation. Namely, the gospel is not contradictory to the culture but plays a positive role in transforming culture.

\section{Missional leadership of Moses in intercultural society}

Moses' remarkable example of leadership originated from his vertical relationship to God and was exercised in various environments. Moses' leadership has fundamentally emanated from his vertical rather than his horizontal relations (Hah 2012:331). That differs from most contemporary leadership theories that emphasise the horizontal part of human relations. God's redemptive leadership towards this world and history had been realised through Moses (Wright 2010:114; Heb 11:24-28).

It affirms God's initiative that Moses did not become a leader of his own will to lead the Israelites out of Egypt. Being called by God, Moses repeatedly pleaded excuses to take the role of leadership (Ex 3:11, 13). God chooses and disciplines his servants on each occasion according to his pleasing will.

Connoted in the Old Testament stories is God's great plan of salvation (Gn 15:16, 18; Ex 3:8) to establish his covenant people and to send Jesus into the world to accomplish the big plan (Heb 11:10). God intended to establish the New Testament church through Christ's redemptive work to renew the whole world in Christ (Eph 1:9-10).

Moses was the first man used by God to cultivate Israel into the people of his covenant according to his pleasing will. When Moses, a Levite, was born, the Israelites were suffering from hard labours in Egypt. Because of the Pharaoh Thutmose I's order that all new-born Hebrew boys had to be killed, Moses was almost thrown into the Nile (Ex 1:22) if it were not for the help of Pharaoh's daughter, Hatshepsut (Ex 2:6, 8). He was nursed by his own mother the Hebrew way, before Hatshepsut took him to her palace and adopted him as her royal son (Ex 2:7-10).

Hatshepsut was married to her stepbrother Thutmose II who ruled over Egypt for 8 years. For they had no son but a daughter between them, Thutmose II begot a son, Thutmose III, from a concubine and let him marry his stepsister. Hatshepsut had ruled over Egypt as a regent because Thutmose III was too young when he was enthroned (Chung 2001:109). As her adopted son, Moses was a grown-up prince when his mother Pharaoh, Hatshepsut, ruled over Egypt with her mighty power. Moses must have been a very stressful politician to Thutmose III at that time (Chung 2001:111).

While struggling with Thutmose III for the power, Moses happened to kill an Egyptian labour inspector and had to flee to the Midian plain (Ex 2:15). It made Moses have a long experience of another culture that is in Midian. There he met a Midian priest and married his eldest daughter and lived for 40 years as a shepherd (Ex 2:15-23; Jdg 1:16; 4:11; Nm 10:29-31; Chung 2001:110-111).

Moses had supposedly been exposed to at least two more cultures, that is, of Canaan and Kenezite, besides the abovementioned three cultures. Moses sent 12 spies, one from each tribe, into the Canaan land when they were in Kadesh Barnea (Nm 13, Dt 1). Though Caleb was the representative of the tribe of Judah, the Bible writes that he was a Kenezite (Nm 32:12; Jos 14:6, 14; Jdg 1:13). Caleb had participated in the holy work, as he was not a blood-Israelite but a faith-Israelite.

That shows Moses as the chief leader was neither confined to the blood tradition nor to discriminate between God's people according to their nationality (Hah 2012:325). Having been already accommodated to intercultural environments through his exposure to various cultures, Moses had the attitude of no racial discrimination in the people of God (like Miriam and Aaron, Nm 12:1). His sending spies reflects his understanding of the culture of the targeted land. In short, Moses had been exposed to, at least, five cultures: Hebrew, Egypt, Midian, Canaan and Kenezite (Hah 2012:324-325).

Though he lived in mixed environments with the five cultures, he showed a leadership embracing and integrating them all. Moses can serve as an example of leadership in a situation where various cultures play a role. Moses understood the mind of God, took his grand and epical leadership as his, and led his people Israel through the desert. Therefore, we can call Moses' leadership 'missional' in the contemporary missiological sense, for he had exercised the redemptive leadership of God in his intercultural environment.

\section{Missional leadership of Jesus in intercultural society}

God's missional leadership is the crucial basis for the completion of Jesus' task that started from the incarnation. The grand and epical plan of redemption of the triune God is revealed in the event of Jesus' incarnation and accomplished 
through his death on the cross and his resurrection, the incarnational concept of the missio Dei were introduced by Vicedom (Haapiainen 2012:50). The incarnation is the essential part of the triune God's leadership, and therefore for the incarnation event is the fundamental basis of the concept of 'missional' (Wright 2010:103).

In the Bible, there are much evidence of Jesus' missional leadership in an intercultural environment. It is well witnessed, specifically at the end of Jesus' public life that he was accustomed to Hellenistic culture. Just before the triumphal entry into Jerusalem to complete his work on the cross, some pious Greeks asked to see Jesus (Jn 12:20-26). When they came to him, Jesus predicted his death and resurrection with an understandable illustration for the Greeks.

The dying of a kernel of wheat was said with the backdrop of a popular Greek story. In Eleusis near Athens, there is a great stone from the 5 th century $\mathrm{BC}$, at which a mysterious religious rite is still carried on at the time of Jesus. Even at Jesus' time, many people participated in the rite, and the story about the stone was famous to all Hellenist worlds. Blaiklock (1997:94) introduces the 'a kernel of wheat' story regarding the Hellenist religion. Bell (1998:248) also explains about the goddess Demeter, the same story of 'a kernel of wheat'.

The two stories differ a little bit in the name of the daughter goddess: the one in Blaiklock's is 'Core', to Bell she is 'Persephone'. Knowing that Core means a virgin, it is plausible that Demeter's daughter, the virgin, was Persephone. The two myths regarding 'a kernel of wheat' are identical.

It can be summarised as follows: Demeter the goddess was in rage and cursed the land with infertility. While she was wandering to search for her daughter, she happened to visit Celeus, the king of Eleusis. Celeus treated Demeter with highest hospitality and later came to know her real identity.

Meanwhile, by the command of Zeus, the highest god of the entire universe, Demeter and Pluto came to a compromise that Persephone would stay for 6 months with her mother and the other 6 months with her husband. Every spring, when she comes home, the land rejoices and the plants produce new life. After the compromise and before coming back home, Demeter gave a kernel of wheat to Triptolemus, the prince of the king of Eleusis, saying: 'Plant this and expect abundant resurrection'.

Using the mysterious story of death and resurrection, Jesus explained his death and its abundant results. By using the famous story inscribed on the great stone in Eleusis near Athens as a parable, Jesus predicted his death, resurrection, and its abundant fruits. Jesus' use of that Greek mythological story when some Greeks came to see him, reflects something of Jesus' communication method.

Besides the above-mentioned Greek religious record, the Bible says that Jesus was born, raised and worked in an intercultural environment. When he was a little boy, he was cared by Joseph and Mary in the Hebrew culture. Although his birthplace was Bethlehem, Mary and her husband took Jesus to Jerusalem to present him to the Lord according to the Law of Moses (Lk 2:22-24; Lv 12:3-4). Jesus had been in Egypt under its culture for 3 years during his early infancy (Mt 3:19-20), from boyhood to adolescence he also experienced some Hellenist culture in Galilee that was known as Galilee of the Gentiles (Mt 4:15). When he was helping Joseph's carpenter work in Nazareth in Galilee, in the vicinity of the big Hellenist city, called Sepphoris.

It implies that Jesus had contact and communication with the Hellenist culture. Sepphoris was less than four miles north of Nazareth (Batey 2006:111). Excavated in 1983, it was a Hellenist city built by Herod Antipas who pursued the Hellenist culture. With about 30000 inhabitants, it was a typical Hellenistic city with a gymnasium, public bath and agora market (Bell, translated by Oh 2001:63).

There were 10 Hellenist cities, called Decapolis, at that time around the Lake of Galilee, both on its eastern and southern sides. Early in Jesus' public life, he was based in Capernaum on the northern coast of the Lake of Galilee, and he often visited Decapolis across the Lake (Mk 5:20; 7:31). It implies that Jesus was accustomed to both Hellenist culture and its language. Jesus was accustomed to the Hellenist and the Canaanite culture. Tyro and Sidon in Phoenicia are the main cities of Canaan region and Jesus went there to evangelise them (Mk 7:24, 31; Mt 15:21-22). No cultural discrimination is witnessed in the composition of his apostles: among the 12, a Jew (Judas Iscariot), some Galileans (Peter and others), a Greek (Philip), and a Canaanite (Simon) (Mt 10:2-4; Mk 3:16-19; Lk 6:13-16).

Evangelism in Samaria was quite an adventure at that time. Samaritans were regarded as a mixed race having even lower status than pagans (Jn 4:3-26). When the kingdom was destroyed by Assyria in 722 BC, according to their migration policy there were many people implanted in the land Samaria (2 Ki 17:24). That Jesus went and evangelised there was an epoch-making event that wiped out the prejudice against a mixed-blood culture.

Jesus lived during the period of Latin colonisation when both Greek and Latin languages were used. Latin was the Roman Empire's official language, and Aramaic and Greek were the common languages.

When Jesus was crucified there was a notice on the cross, written in Aramaic, Latin and Greek (Jn 19:20).

Both in Jerusalem and in Capernaum, there were Roman troop camps. The environment of Jesus was intercultural. At least seven cultures were co-existing: Hebrew, Egyptian and Canaanite, mixed-blood Samaritan, Aramaic, Greek and Roman.

Jesus integrated his own redemptive and messianic leadership style with those cultures in the gospel (see his followers in Mt 4:24-25). In his intercultural environment 
with many languages, cultures, religions and ethnic cultures, Jesus exercised his missional leadership with the purpose of saving this world according to the will of the triune God through his incarnation and establishment of the kingdom of God. His work on the cross reveals his attitude of self-committing through the Holy Spirit, which recalls his going out to the desert to be tempted by the devil being led by the Holy Spirit. Like a lamb dragged to the slaughterhouse, he restrained himself solely depending on the Holy Spirit. Though it looked like a passive life, it was the most active life.

\section{Missional leadership of the apostle Paul in intercultural society}

The leadership of the apostle Paul is also missional, aiming at the glory of God (Cho 2011:109; Rm 8:19-22; Isa 66:19). His leadership shows his dependence on and commitment to the Holy Spirit (Rm 19:26-27; Ac 20:23-25; 21: 5-6; 23: 11). Paul not only established churches in Asia Minor (at that time, called Asia) for almost 10 years but also nurtured them and tried to change their worldview with letters or by visiting them, or by sending his agents (Riesner 1998:277).

The main centre of his evangelism of Asia Minor was his work in Ephesus. It was partly because of his missionary journeys that in a relatively short period of time he could evangelise the whole region of Asia Minor, and partly because of his work at the lecture hall of Tyrannus in Ephesus. When he worked in Ephesus, 52-55 AD, the seven churches written in the book of Revelation were established: Ephesus, Smyrna, Pergamum, Thyatira, Sardis, Philadelphia and Laodicea. Two more churches were also established in the same period: in Colossae and Hierapolis (Blaiklock 1997:940:703).

Barnabas brought Paul to Antioch to work with them and the apostle Paul also played a key role (Ac 4:36; 11:25-26). Barnabas was a good man, full of the Holy Spirit and faith (Ac 11:24). In Antioch, the number of members was increased in 1 year, and they were called by the nickname of Christians. Joseph, a Levite from Cyprus, whom the apostles called Compared to him, Paul was a man of logic, strict and passionate. The characteristics of Paul's leadership are revealed in his work: initiative, affirmative and considerably versatile.

After the second missionary journey that kept him for a year and a half in Corinth (Ac 18:11), Ephesus was the next centre of his work for 3 years during his third missionary journey (Ac 18:11, 18). It was the fourth biggest city with a population of 500 000, the most religious city in the whole Roman Empire, and the capital of the Roman province Asia. The apostle Paul showed a missional leadership in that he had seen the mission of gospel preaching in the wider perspective of a big picture. He had already received a mission with his conversion experience on the road to Damascus (Ac 9:1-19).

There are many hints that reveal Paul's big picture understanding of the Bible. For example, he was chosen by
God to be the first writer of the New Testament - all his letters were written before the Gospels - to explain the meaning of the death and resurrection of Jesus as the way of salvation for all peoples (G1 3:26-29); he understood the relationship between man and woman as the relationship between Christ and the church (Eph 5:25-33; 1 Tm 2:12-15); he understood the gospel of Jesus Christ in the big picture of God's dealing with his world and his church (Eph 1:17-23). Ultimately, his efforts and intentions for mission were aiming at the glory of the Lord (Eph 3:14-21).

Roland Allen (1868-1947, [1912] 2015:17-19), an Anglican missionary to China for 8 years (1895-1903), asserts that the churches that the apostle Paul established play a role as centres of Christian life as follows: 'Paul's theory of evangelizing a province was not to preach in every place in it himself, but to establish centres of Christian life in two or three important places'.

Allen (2015:17-19) says that Luke and Paul testify that the apostle Paul set the establishment of the church according to the limits of Roman administration, yet they spoke the gospel in rural areas like a Derbe, Lystra or Iconium. Allen also explains that Paul intentionally was showing not town or village itself but his congregation that built for kingdom of God. As Allen asserted in his conclusion, it is certain Paul had an intentional strategy with missional leadership.

The road that Paul took on his second missionary journey shows his missional leadership was well-designed according to his perspective of the big picture. On the way to Antioch from Corinth, he happened to pass Ephesus. It was not coincidently. He intentionally planned the course. If it was the Lord's will, he planned to make Ephesus his mission centre preaching the gospel to the whole of the province Asia. Paul intentionally let the Aquila couple stay in Ephesus, took every chance to preach in synagogues and promised to come back if it is God's will (Ac 18:16-21).

During his third missionary journey he focused on the evangelisation of the Asia province. Asia was the strategic mission base for Paul. At the centre of the province there was Ephesus. That the last destination of Paul's third missionary journey was Ephesus shows well of his intention. It shows well that Paul went around inland of Asia Minor before going to Ephesus. He started his mission there with baptising 12 Jews who were baptised in the name of John the Baptist. He baptised them in the name of Jesus and led them to receive the Holy Spirit by laying his hands on them (Ac 19:1-7). Missionary life wholly committed to the Holy Spirit was the secret why Paul gathered fruits of mission from Asia Minor and Macedonia.

It must have been very encouraging in missionary perspective to see Paul establishing a new culture based on the gospel with no compromises with the Ephesians culture. A number who had practised sorcery brought their scrolls and burned them publicly (Ac 19:19). In most cases in the field, apostle 
Paul kept the principle of Christ's Law, not to be confined to religious rites or traditions (1 Cor 9:20-23).

His capacity of embracing cultures was incommensurable. Wherever he went, he taught the word of the Old Testament scriptures proclaiming that they were fulfilled by Jesus Christ. He spent much time in his teaching ministry to make the disciples grow in faith. Paul's missional leadership was through embrace and generosity. However, in doing so, he did not jeopardise anything to corrupted cultures. His leadership was apparent in his Antioch church ministry and all the churches planted throughout the Roman provinces in Asia Minor, and in Macedonia and Greece.

\section{Conclusion}

This article explored theological constructs and three biblical narratives for missional leadership. The research illustrates three approaches: first, missional leadership is generated and nurtured by two elements: the ceremony of baptism and discipleship. The two elements share the commonality of attesting to Jesus is Christ. The content of the confession is to accept and to spread both the incarnation and the fulfilment of the work of the cross, Death and Resurrection, through missional leadership. Therefore, missional leadership is in pursuit of the salvation of human beings beyond its borders, and in pursuit of the restoration and consummation of God's corrupted order of creation. Missional leadership is also in regards to the restoration of man's duty to appropriately oversee all creatures as God's image bearer. This idea illustrates people who confess their faith in Christ to regain and to strengthen the authority of their cultural mandate as God's image through the missional leadership.

Secondly, the researcher found that there is a theological relevance in missiology between the missional concept and the biblical worldview in a holistic view of the Bible. Many scholars emphasise that the biblical perspective indicates that the Bible is not merely a catechism for the salvation of man, but also a message of redemptive history. The history shows a stepwise and gradual progression towards a specific goal. This goal is comprised of four historical phases in the progression of revelation as the following: creation, fall, redemption and restoration. It implies Christians, as both the church and God's witnesses, should go and reach out to the world with mercy, and try to transform their communities. This illustrates the concept of missional as serving the world with the biblical worldview. Thus, the biblical worldview and the idea of 'missional' are inextricably related.

Thirdly, it reached the conclusion that missional leadership can be approached from the viewpoint of the cultural mandate. The cultural mandate was given to the first couple, Adam and Eve. From there, all humankind was to rule over the world and all the creatures living in the world according to his will (Gn 1:28). Missional leadership was given to humans as the first command from the triune God's missional leadership, restored and re-empowered in accepting Jesus as Christ since the fallen status of the origin sin.
This argument leads to the conclusion that the missional leadership of the triune God is being carried to the world, through man to the world, through man in the image of God. Man is the most important axis in maintaining the order of creation.

Fourthly, Jesus, Moses and Paul are examples of missional leadership. The three exemplary leaders were both situated in an intercultural environment accustomed to the direction of redemptive history. They strived to achieve the redemptive plan of the triune God as an example to their generations. Moses acted under at least five cultures; Jesus at least seven. Being conversant in both Hebrew and Greek cultures, Paul showed the principle of Christ's law to embrace gentiles with a missional attitude. Those three were typical role models of missional leadership who tried their best to fulfil the redemptive plan of the triune God.

In conclusion, this study confirms that intercultural missional leadership is same in position of the redemptive-historical perspective in biblical theology. Both have the same goal to accomplish God's kingdom, integrating and interacting all cultures according to the historical phases of the biblical worldview: creation, fall, redemption and restoration. It also validates that Moses, Jesus and Paul exemplify the typical, biblical narrative of intercultural missional leadership. When playing a role in the leadership of the triune God, the intercultural missional leadership reveals itself more properly, just as it did for Moses, Jesus and Apostle Paul.

\section{Acknowledgements Competing interests}

The author declares that he or she has no financial or personal relationships that may have inappropriately influenced him or her in writing this article.

\section{References}

Allen, R., [1912] 2015, Missionary methods: St. Paul's or ours, a study of the church in the four provinces, Forgotten Books, London.

Anderson, B.W., 1994, From creation to new creation: Old Testament perspectives, Augsburg Fortress, Minneapolis, MN.

Baker, W.H., 1991, In the image of God: A Biblical view of humanity, Moody Publishers, Chicago, IL.

Batey, R.A., 2006, 'Did Antipas build the Sepphoris theatre?', in J.H. Charlesworth (ed.), Jesus and archaeology, pp. 111-119, William B. Eerdmans Publishing Company, Grand Rapids, MI.

Bavinck, J.H., 1960, An introduction to the science of missions, Presbyterian and Reformed Pub. Co., Philadelphia, PA.

Bell, A.A., 1998, Exploring the New Testament world, transl. K. M. Oh, 2001, Word of Life Press, Seoul, Korea.

Berkouwer, G.C., 1984, Man: The image of God, reprinted, William B. Eerdmans Publishing Co., Grand Rapids, MI.

Blaiklock, E.M., 1997, The world of the New Testament, transl. Korean Scripture Union, Ark Publishing, Seoul, Korea.

Buys, P.J. (Flip), 2013, 'A missional response to poverty and social injustice', in S.T. Logan (ed.), Reformed means Missional: Following Jesus into the World, New Growth Press, Greensboro, NC.

Callahan, S.H., 2009, 'Forming lay missional leaders for congregations and the world', in C. Van Gelder (ed.), The missional church: Helping congregations develop leadership capacity, pp. 120-146, William B. Eerdmans Publishing Company, Grand Rapids, MI.

Calvin, J., 2008, Institutes of the Christian Religion, Hendrickson Publishers, Peabody, MA. Cho, K.H., 2011, Paul who leads man and world, The Christian Literature Society of Korea, Seoul, Korea. 
Chung, G.-H., 2001, Old Testament, exposed by archaeology, 3rd edn., Little Fortune press, Seoul, Korea.

De Graaf, S.G., [1977] 2011, Promise and deliverance I, trans. S. Hwang, Pyongdan Munhwasa, Seoul, Korea.

Elton, T.M., 2009, 'Forming lay missional leaders for congregations and the world', in C. Van Gelder (ed.), The missional church: Helping congregations develop leadership capacity, pp. 175-208, William B. Eerdmans Publishing Company, Grand Rapids, MI.

Goheen, M.W., 2014, Introducing Christian mission today: Scripture, history and issues, InterVarsity Press, Downer Grove, IL.

Goldsworthy, G., 2012, Christ-Centered biblical theology: Hermeneutical foundations and principles, InterVarsity Press, Downers Grove, IL.

Haapiainen, T.-M., 2012, 'The development and outlines of missio Dei' in G.F. Vicedom's theology', SMT: Svensk Missionstidskrift/Swedish Missiological Themes 100(1), 45-64.

Hah, S.M., 2012, 'Reformed intercultural leadership: Focusing on the Pentateuch', Korea Reformed Journal 24, 301-334.

Hah, S.M., 2013, 'Jesus' intercultural leadership: Focusing on the gospels', Korea Reformed Journal 26, 177-204.

Hah, S.M., 2015, 'Biblical leadership understanding in reformed worldview', Faith \& Scholarship 20, 137-158.

Hamilton, J.M., Jr., 2014, What is biblical theology: A guide to the Bible's story, symbolism, and patterns, Crossway, Wheaton, IL.

Helm, P., 1994, The providence of God: Contours of Christian theology, InterVarsity Press, Owners Grove, IL.

Hoekema, A.A., [1986] 1994, Created in God's image, 5th edn., Wm. B. Eerdmans Publishing Co., Grand Rapids, MI.
Jongeneel, J.A.B., 1991, 'The missiology of Gisbertus Voetius: The first comprehensive protestant theology of missions', Calvin Theological Journal 26(1), 47-79.

Kaiser, W.C., Jr., 2008, The promise-plan of God: A biblical theology of the Old and New Testaments, 2nd edn., Zondervan, Grand Rapids, MI.

Kirk, J.A., 2000, What is mission: Theological explorations, Fortress Press, Minneapolis, MN.

Logan, S.T. (ed.), 2013, Reformed means missional: Following Jesus into world, New Growth Press, Greensboro, NC.

Ott, C., Strauss, S.J. \& Tennent, T., 2010, Encountering Theology of Mission: Biblical foundations, historical developments, and contemporary issues, Baker Academic Publishing, Ada, MI.

Riesner, R., 1998, Paul's early period: Chronology, mission strategy, Theology, Wm. B. Eerdmans Publishing, Grand Rapids, MI.

Schuster, J., 2002, 'Karl Hartenstein: Mission with a focus on the end', Mission Studies 19(1), 53-81. https://doi.org/10.1163/157338302X00053

Schwarz, G., 1984, 'The legacy of Karl Hartenstein', International Bulletin of Missionary Research 8(3), 125-131. https://doi.org/10.1177/239693938400800307

Van Gemeren, W.A., 1988, The progress of redemption: The story of salvation from creation to the New Jerusalem, Zondervan, Grand Rapids, MI.

Vos, G., 1948, Biblical theology: Old and New Testaments, Wm. B. Eerdmans Publishing Co, Grand Rapids, MI.

Wolters, A.M. \& Goheen, M.W., 2005, Creation regained: Biblical basics for a reformational worldview, Wm. B. Eerdmans Publishing Co., Grand Rapids, MI.

Wright, C.J.H., 2006, The Mission of God: Unlocking the Bible's grand narrative, InterVarsity Press, Downers Grove, IL.

Wright, C.J.H., 2010, The Mission of God's people: A biblical theology or the Church's mission. Zondervan, Grand Rapids, MI. 